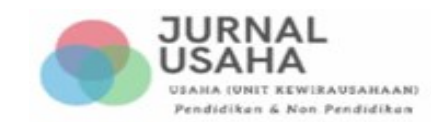

Vol 1, No. 2 (2020), Desember 2020

E-ISSN: 2746-2471, DOI:

\title{
KINERJA USAHA BUMDES DI KABUPATEN BEKASI DIPENGARUHI OLEH ORIENTASI KEWIRAUSAHAAN, TEKNOLOGI DIGITAL KEWIRAUSAHAAN DAN MOTIVASI USAHA.
}

\author{
Indra Permana \\ Fakultas Ekonomi Bisnis dan Ilmu Sosial \\ Universitas Pelita Bangsa \\ indrapermana@pelitabangsa.ac.id
}

Dikirim:12 Desember 2020 Direvisi:26 Desember 2020 Dipublikasikan: 31 Desember 2020

\begin{abstract}
ABSTRAK
Keberadaan BUMDes sebagai salah satu lembaga pedesaan dan menjadi pelopor penggerak ekonomi desa di Kabupaten Bekasi yang diharapakan mampu meningkatka kesejahteraan warganya. Namun dalam pelaksanaanya ditemui beberapa permasalahan, diantaranya Adalah Kuarangnya sosialisasi BUMDes, Kurangnya kerja sama antar BUMDes, serta belum banyaknya pemanfaatan teknologi digital yang di implikasikan oleh BUMDes.Penelitian ini bertujuan untuk menguji pengaruh orientasi kewirausahaan pada kinerja usaha. Menguji pengaruh teknologi digital kewirausahaan pada kinerja usaha. Menguji pengaruh motivasi usaha pada kinerja usaha. Serta bertujuan supaya BUMDes dapat meningkatkan inovasi-inovasi baru di kelembagaan badan usaha milik desa, berkaitan dengan pendapatan desa dan pemanfaatannya untuk sosial. Metode pengambilan sampel yang digunakan adalah probability sampling yaitu dengan metode simple random sampling. Sampel dalam penelitian ini adalah 32 BUMDes di Kabupaten Bekasi. Penelitian ini didasarkan pada uji validitas dan reliabilitas instrument dan hubungan yang dihipotesiskan di dalam model teoritis yang diusulkan. Temuan dari model struktural telah membutikan hampir semua hubungan variabel yang dihipotesiskan terbukti terdukung. Hasil penelitian membuktikan bahwa terhadap pengaruh positif orientasi kewirausahaan pada kinerja usaha. Terdapat pengaruh teknologi digital kewirausahaan pada kinerja usaha. Terdapat pengaruh motivasi usaha pada kinerjausaha.
\end{abstract}

Kata Kunci: Orientasi Kewirausahaan, Teknologi Digital Kewirausahaan, Motivasi Usaha

\section{A. PENDAHULUAN}

Perkembangan ekonomi global meningkat setiap tahun, peningkatan ini disebabkan oleh adanya inovasi, teknologi yang berkembang, serta peraturan pendukung dari pemerintah untuk mengawasi kegiatan perekonomian Indonesia. Peningkatan tersebut ada pada permintaan barang dan jasa baik secara kuantitas dan 


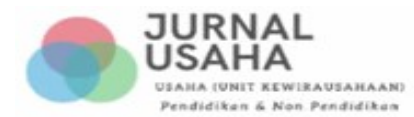

Vol 1, No. 2 (2020), Desember 2020

E-ISSN: 2746-2471, DOI:

mutu kualitas. Ekonomi yang bersifat membangun kesejahteraan masyarakat dan peningkatan pendapatan Negara. Perubahan perekonomian Indonesia, melalui potensi yang ada di setiap daerah untuk membangun kemandirian ekonomi masyarakat dan penciptaan inovasi-inovasi baru yang berkelanjutan. Dalam upaya tersebut maka perlu adanya menggali potensi ekonomi pedesaan serta memberdayakan potensi lokal melalui badan usaha milik desa (BUMDes). Pada saat ini keberadaan BUMDes masih belum bisa berjalan efektif dan mampu memberi kontribusi bagi pembangunan dan pemberdayaan masyarakat di desa (Prasetyo, 2016). Terkaitan dengan hal tersebut perlu adanya gagasan dan pemikiran untuk membentuk badan usaha milik desa (BUMDes) sesuai dengan UU Desa No.6 Tahun 2014 tentang desa. Dalam undang-undang ini, desa disebut secara definitif dan keberadaan badan usaha milik desa diakui, yaitu disebut dalam pasal 213 ayat (1) desa dapat mendirikan badan usaha milik desa sesuai dengan kebutuhan dan potensi desa (Ridlwan, 2015). Badan usaha milik desa (BUMDes) dibentuk agar menjadi roda perekonomian desa secara mandiri guna mencapai peningkatan kesejahteraan warganya.

Perkembangan pendirian BUMDes di Indonesia pada September 2018 telah mencapai angka sekitar 39.000 BUMDes di Indonesia, dari 74.958 Desa yang ada di Indonesia. Dengan demikian secara nasional perkembangan pendirian BUMDes di Indonesia telah mencapai 50\% yang memiliki BUMDes, dilansir data olahan dari Kementerian Desa (Kemendesa, 2020). Berdasarkan asumsi itulah maka sudah seharusnya eksitensi desa dapat mendirikan BUMDes dengan kemandirian dan pemanfaatanpotensiyang ada di desa. Kemandirian Desa dapat dibentuk melalui pendekatan serta kesungguhan dalam menjalankan tugas yang telah diberikan kepada pengelola Desa.

Di Kabupaten Bekasi sendiri pendirian BUMDes menurut data lansiran dari data Dinas PMD (dinas pemberdayaan masyarakat dan desa) Kabupaten Bekasi, dari total 180 Desa yang ada di Kabupaten Bekasi yang telah memiliki BUMDes berjumlah160. Namun jumlah BUMDes di Kabupaten Bekasi yang ada saat ini digolongkan berdasarkan temuan Dinas PMD Kabupaten Bekasi, menggolongkan dalam 3 kategori: (1) BUMDes yang diakui sudah beridiri tapi tidak memiliki nama, (2) BUMDes yang diakui sudah memiliki nama namun tidak ada penggurusdan (3) ada nama BUMDes, ada pengurus, namun tidak ada regulasi (DPMD kabupaten bekasi, 2020).

Penelitian ini bertujuan, supaya kinerja badan usaha milik desa dapat meningkat dalam pemberdayaan didalam masyarakat serta kesejahteraan warga sekitar. Serta meningkatkan inovasi-inovasi baru di kelembagaan badan usaha milik desa, berkaitan dengan pendapatan asli desa dan pemanfaatannya untuk sosial warga sekitar Desa.

\section{B. KAJIAN PUSTAKA}

Kewirausahaan dapat diartikan sebagai kemampuan seseorang dalam mencari 


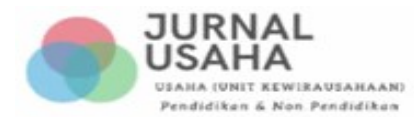

Vol 1, No. 2 (2020), Desember 2020

E-ISSN: 2746-2471, DOI:

peluang serta berinovasi kreatif dalam pemanfaatan sumber daya yang ada untuk menuju kesuksesan. Orientasi kewirausahaan adalah menentukan sikap serta mercenanakan peluang dalam kewirausahaan untuk mencapai tujuan dari berorientasi. Manajemen memberikan tiga landasan dimensi-dimensi dari kecenderungan organisasional untuk manajemen kewirausahaan, yakni kemampuan berinovasi, kemampuan mengambil risiko, dan sifat proaktif (Suryanita, 2016).

Penelitian ini akan menggunakan indikator kinerja organisasi. Dimana dalam menganalisis kinerja badan usaha milik desa dalam meningkatkan pendapatan asli desa, di Desa Cikarang Kota, Kecamatan Cikarang Utara, Kabupaten Bekasi yang terdiri atas indikator produktivitas, kualitas layanan, dan responsivitas (Dwiyanto, 2017).

Kinerja merupakan hasil pekerjaan yang mempunyai hubungan kuat dengan tujuan strategi organisasi, kepuasan konsumen, dan memberikan kontribusi pada ekonomi (Lawasi \& Triatmanto, 2017). Dengan demikian kinerja adalah suatu pekerjaan yang akan dilakukan untuk mencapai suatu keberhasilan. Kemudian pada kinerja organisasi berkaitan dengan pencapaian organisasi pada kualitas atau kuantitas analisis organisasi. Kinerja merupakan sesuatu hal penting dalam menunjang keberhasilan organisasi atau lembaga bumdes.

Teknologi digital kewirausahaan merupakan kapasitas kewirausahaan dalam pemanfaatan teknologi untuk keberlangsungan usaha. Konseptualisasi teknologi kewirausahaan merupakan kombinasi dari kewirausahaan dan inovasi berbasis teknologi (Marques \& Ferreira, 2009). Peningkatan kinerja pada badan usaha milik desa dapat melakukan inovasi yang berbasis teknologi digital kewirausahaan. Sebagian besar tantangan teknologi berasal pada pendatang baru atau peralihan antar industri kormesil pada era teknologi digital. Dimana pengusaha harus miliki misi untuk menciptakan pasar untuk teknologi baru dan kompleks (Giones \& Brem, 2017b).

Perubahan pada aktivitas kewirausahaan derngan adanya digitalisasi maka tidak hanya mengubah pola tradisional tetapi secara keseluruhan proses berwirausaha. Dari perspektif penelitian, kewirausahaan digital adalah lebih dekat dengan konsep sistem informasi artefak, platfom, dan infrastuktur informasi (Giones \& Brem, 2017a).

Wirausaha adalah individu yang berjiwa berani mengambil risiko untuk memulai suatu usaha dalam berbagai kesempatan yang ada. Selanjutnya, dorongan minat tersebut serta perecanaan yang sesuai dengan kebutuhan bidang usaha. Motivasi adalah faktor-faktor yang ada dalam diri seseorang yang menggerakkan, mengarahkan perilakunya untuk memenuhi tujuan tertentu. Motivasi merupakan kegiatan seseorang dalam melalukan pekerjaan dimulai dengan minat yang tinggi dalam pencapaian tujuan. Proses terbentuknya motivasi mulai dari kebutuhan yang menjadikan dorongan seseorang untuk melakukan sesuatu dalam pencapaian tujuan (Puby Carolina, 2015).

Motivasi usaha merupakan sebuah dorongan yang tumbuh dalam diri 
seseorang (Sunyoto, 2012). Dorongan seseorang dalam memulai usaha untuk mencapai tujuan yaitu laba atau keuntungan yang didapatkan sehingga keputusan seseorang untuk berwirausaha atau bekerja pada orang lain merupakan proses rasional.

Dalam mengukur motivasi sesesorang maka dilihat dari keinginan untuk mencapai: (1) laba usaha merupakan kelebihan pendapatan dibandingkan total beban disebut juga pendapatan bersih atau net earnings (LIN \& LIU, 2013). (2) Impian usaha adalah keinginan memiliki suatu kebutuhan dengan tujuan menghasilkan pendapatan dan (3) kebebasan usaha merupakan keadan bebas dalam kemampuan percencanaan usaha serta kemampuan merumuskan tujuan yang ingin dicapai (Gemina, Silaningsih, \& Yuningsih, 2016).

Dari konsep tersebut maka terbentuklah kerangka pemikiran yang merupakan gabungan dari teori penelitian sebelumnya yang relevan dan pemikiran logis yang digunakan untuk menduga keterkaitan antara masalah yang diteliti sesuai dengan gambar 1 .

Gambar 1.

Kerangka pemikiran

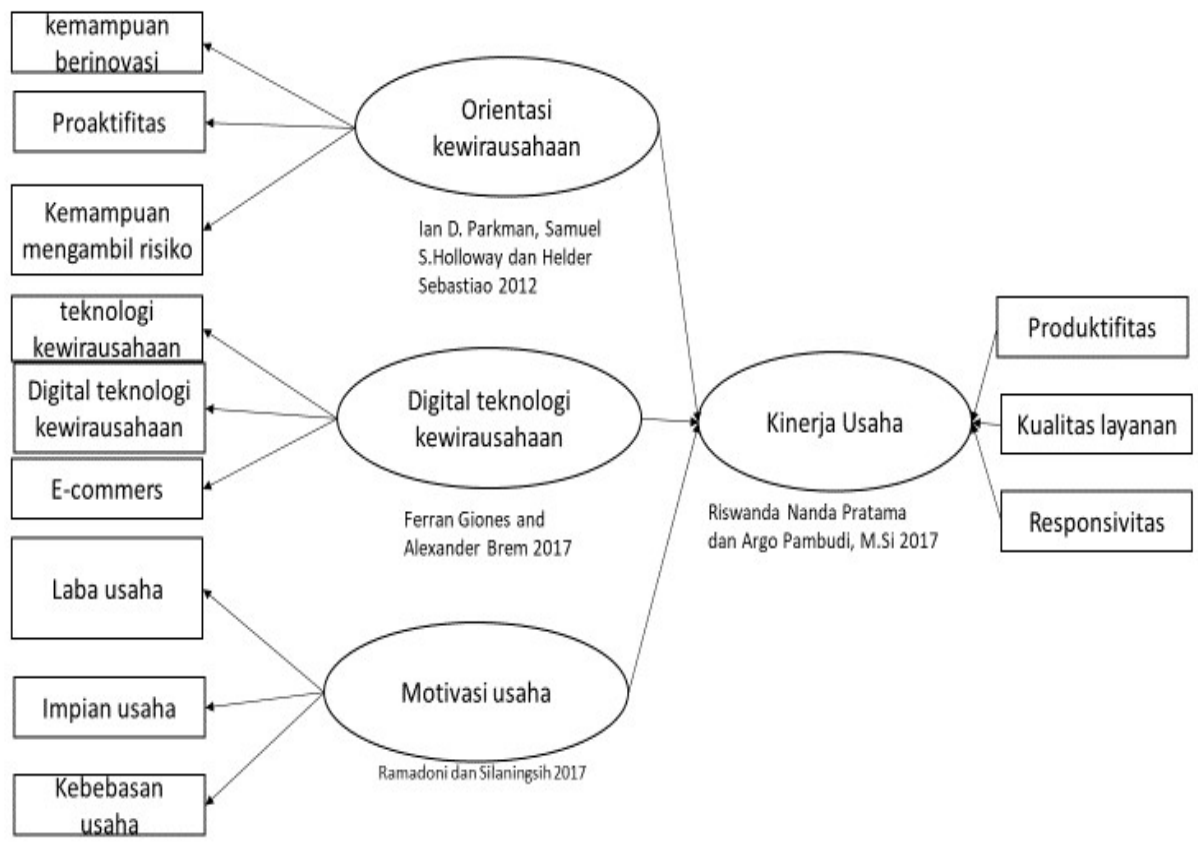

\section{METODE PENELITIAN}

Penelitian ini termasuk ke dalam penelitian kuantitatif. Penelitian ini dilaksanakan di Badan usaha milik desa, di Kabupaten Bekasi. Berdasarkan pada tujuan penelitian, ingin menguji orientasi kewirausahaan, teknologi digital 


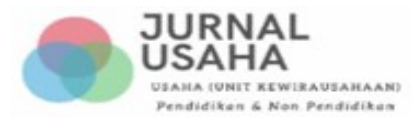

Vol 1, No. 2 (2020), Desember 2020

E-ISSN: 2746-2471, DOI:

kewirausahaan serta motivasi usaha dalam membantukinerja usaha. Metode yang digunakan dalam penelitian ini adalah metode penelitian kepustakaan. Di Kabupaten Bekasi terdapat populasi 160 BUMDes data dari olahan tahun 2019 Dinas PMD (Dinas Pemberdayaan Masyarakat Dan Desa) Kabupaten Bekasi. Namun yang dipelajari oleh penulis hanya 32 sampel BUMDes. Selanjutnya, Teknik pengumpulan data yang dilakukan penulis dalam penelitian ini adalah teknik kuesioner dan teknik observasi. Untuk menganalisis data yang diperoleh dari hasil penelitian penulis menggunakan metode statistik dengan cara uji validitas, uji realibilitas, uji asumsi klasik, uji heteroskedastisitas, analisis regresi berganda, dan uji hipotesis.

\section{HASIL DAN PEMBAHASAN}

Di Kabupaten Bekasi terdapat populasi 160 BUMDes data dari olahan tahun 2019 Dinas PMD (dinas pemberdayaan masyarakat dan desa) Kabupaten Bekasi. Namun yang dipelajari oleh penulis hanya 32 sampel BUMDes, terdapat temuan sebagai berikut, pertama sedikitnya jumlah BUMDes yang maju di Kabupaten Bekasi. Hal itu disebabkan rata-rata usia BUMDes relatif masih baru atau kurang dari lima tahun, usia BUMDes yang tergolong muda ini juga disebabkan adanya pergantian pengelola BUMDes sebagai dampal dari pergantian kepala Desa. Kedua, popularitas kehadiran BUMDes masih minim ditengah-tengah masyarakat.

Pada penelitian ini BUMDes dapat memperhatikan variabel-variabel yang penulis teliti dalam mewujudkan dan terciptanya BUMDes yang berkembang serta bersinergi antar lembaga BUMDes untuk mewujudkan tercapainya visi dan misi BUMDes di Kabupaten Bekasi. melalui tahapan pemahan tentang orientasi kewirausahaan, prioritas dalam kinerja usaha BUMDes sudah seharusnya memperhatikan orientasi, arah visi dan misi BUMDes dalam mengembangkan kinerjausahaBUMDes. Melibatkan ahli profesional dalam pengelola BUMDes demi terbentuknya BUMDes yang maju dan populer dimasyarakat,dengan pemanfaatan teknologi digital kewirausahaan. Teknologi digital dalam pengelolaan BUMDes harus di manfaatkan sebaik- baiknya atau merekrut ahli professional dalam bidang teknologi digital untuk memasarkan produk, sosialiasi BUMDes yang sudah berdiri melalui daring media sosial. Masa pandemi covid-19 teknologi digital dapat dimanfaatkan BUMDes untuk memasarkan produk dan mempertahakan eksistensi BUMDes yang berada di Kabupaten Bekasi. Serta pengurus yang berintegritas dalam motivasi usaha pengelolaan BUMDes,haltersebutmempengaruhi keberlangsungan BUMDes. Motivasi usaha pada kepengurusan BUMDes harus mencerminkan Pribadi berwirausaha.

Selanjutnya untuk membuktikan adanya hipotesis, maka mengaitkan dengan hasil yang telah diperoleh dari hasil penelitian terhadap fokus kajian "Pengaruh Orientasi Kewirausahaan, Teknologi Digital Kewirausahaan Dan Motivasi Usaha Terhadap Kinerja Usaha Bumdes Di Kabupaten Bekasi”. Hasil dari perhitungan statistik penelitian ini menunjukan terdapat pengaruh variabel bebas terhadap 


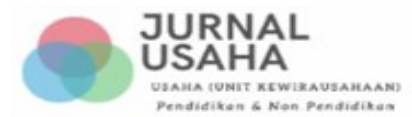

Vol 1, No. 2 (2020), Desember 2020

E-ISSN: 2746-2471, DOI:

variabel terikat. Berdasarkan perhitungan statistik, diperoleh $\mathrm{Y}=1,308+0,129$ $\mathrm{X} 1+0,723 \mathrm{X} 2+0,087 \mathrm{X} 3$.

Berdasarkan hasil penelitian menunjukan bahwa secara statistik dari ketiga hipotesis yang diajukan semua yang mendukung berdasarkan teori sebelumnya, dapat disimpulkan bahwa, (1) Terdapat pengaruh positif dan signifikan antara orientasi kewirausahaan terhadap kinerja usaha. Berdasarkan hasil olah data uji parsial untuk variabel orientasi kewirausahaan dengan nilai $t_{\text {hitung }}=1,812$ dengan nilai signifikan 0,236 dengan probabilitas signifikan lebih besar dari 0,05 dan nilai

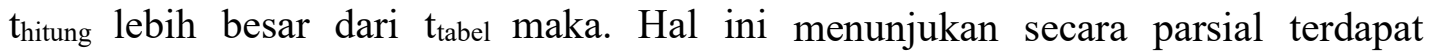
pengaruh variabel orientasi kewirausahaan terhadap kinerja usaha. (2) Terdapat pengaruh positif dan signifikan antara teknologi digital kewirausahaan terhadap kinerja usaha. Berdasarkan hasil olahan data uji parsial untuk variabel teknologi digital kewirausahaan dengan nilai $t_{\text {hitung }}=5,250$ dengan nilai signifikan 0,000 dengan probabilitas signifikan lebih kecil dari 0,05 dan nilai thitung lebih besar dari $t_{\text {tabel }}$ maka. Hal ini menunjukan secara parsial terdapat pengaruh variabel teknologi digital kewirausahaan terhadap kinerja usaha. (3) Terdapat pengaruh positif dan signifikan antara motivasi usaha terhadap kinerjausaha.Berdasarkan hasil olahan data uji parsial untuk variabel motivasi usaha dengan nilai $t_{\text {hitung }} 1,997$ dengan nilai signifikan 0,327 dengan probabilitas signifikan lebih besar dari 0,05 dan nilai thitung lebih besar dari thitung maka. Hal ini menunjukan secara parsial terdapat pengaruh variabel motivasi usaha terhadap kinerjausaha.

\section{E. SIMPULAN}

Simpulan yang diperoleh dari hasil penelitian adalah orientasi kewirausahaan memiliki pengaruh positif terhadap variabel kinerja usaha dan teknologi digital kewirausahaan memiliki pengaruh positif terhadap variabel kinerja usaha, serta motivasi usaha memiliki pengaruh positif terhadap variabel kinerja usaha.

Dalam kesempatan ini penulis mencoba untuk menyampaikan saran yang terkait dengan penelitian ini yaitu sebagai berikut:

1. BUMDes di Kabupaten Bekasi diharapkan dapat menerapkan berbagai indikator variabel orientasi kewirausahaan, teknologi digital kewirausahaan, dan motivasi usaha untuk meningkatkan kinerja usaha BUMDes.

2. BUMDes di Kabupaten Bekasi harus mampu berkerjasama antar BUMDes untuk eksistensi keberadaan BUMDes dimasyarakat lingkungan sekitar.

3. BUMDes di Kabupaten Bekasi harus mampu menafaatkan teknologi digital dalam pemanfaataan e-commers untuk meningkatkan perolehan BUMDes. 


\section{DAFTAR PUSTAKA}

DPMD kabupaten bekasi. (2020). Website Resmi Kabupaten Bekasi. Retrieved October 9, 2019, from website

Dwiyanto, A. (2017). Manajemen Pelayanan Publik: Peduli Inklusif dan Kolaborasi. In UGM Press.

Gemina, D., Silaningsih, E., \& Yuningsih, E. (2016). Pengaruh Motivasi Usaha terhadap Keberhasilan Usaha dengan Kemampuan Usaha sebagai Variabel Mediasi pada Industri Kecil Menengah Makanan Ringan Priangan TimurIndonesia. Jurnal Manajemen Teknologi. https://doi.org/10.12695/jmt.2016.15.3.6

Giones, F., \& Brem, A. (2017a). Digital Technology Entrepreneurship: A Definition and Research Agenda. Technology Innovation Management Review. https://doi.org/10.22215/timreview1076

Giones, F., \& Brem, A. (2017b). From toys to tools: The co-evolution of technological and entrepreneurial developments in the drone industry. Business Horizons. https://doi.org/10.1016/j.bushor.2017.08.001

Kemendesa. (2020). Pusat Data Desa Indonesia.

Lawasi, E. S., \& Triatmanto, B. (2017). PENGARUH KOMUNIKASI, MOTIVASI, DAN KERJASAMA TIM TERHADAP PENINGKATAN KINERJA KARYAWAN. JURNAL MANAJEMEN DAN KEWIRAUSAHAAN. https://doi.org/10.26905/jmdk.v5i1.1313

LIN, D., \& LIU, M. (2013). Provision for Bad Debts and Corporate Earnings Quality: Evidence from A-share Listed Companies. Journal of Nanjing Audit University.

Marques, C. S., \& Ferreira, J. (2009). SME innovative capacity, competitive advantage and performance in a "traditional" industrial region of Portugal. Journal of Technology Management and Innovation. https://doi.org/10.4067/S0718-27242009000400005

Prasetyo, R. A. (2016). Peranan Bumdes Dalam Pembangunan dan Pemberdayaan Masyarakat Di Desa Pejambon Kecamatan Sumberrejo, Kabupaten Bojonegoro. Jurnal Dialektika.

Puby Carolina, V. (2015). Pengaruh tingkat pendidikan dan motivasi wirausaha terhadap penggunaan bootstrap financing. Journal of Business \& Banking. https://doi.org/10.14414/jbb.v5i1.469

Ridlwan, Z. (2015). Payung Hukum Pembentukan BUMDes. FIAT JUSTISIA:Jurnal Ilmu Hukum. https://doi.org/10.25041/fiatjustisia.v7no3.396 


\section{JURNAL

Vol 1, No. 2 (2020), Desember 2020

E-ISSN: 2746-2471, DOI:

Sunyoto, D. (2012). Dasar - Dasar Manajemen Pemasaran. In dasar dasar manajemen pemasaran.

Suryanita, A. (2016). ANALISIS PENGARUH ORIENTASI KEWIRAUSAHAAN DAN KOMPETENSI PENGETAHUAN TERHADAP KAPABILITAS UNTUK MENINGKATKAN KINERJA PEMASARAN (Universitas Diponegoro.). Retrieved from http://eprints.undip.ac.id/15358/ 